Ukrainian Journal of Nephrology and Dialysis
Scientific and Practical, Medical Journal

\section{Nephrology School}

doi: 10.31450/ukrjnd.4(64).2019.08

\section{N.G. Aleksieieva}

\section{Advantages of expanded hemodialysis (HDx) over standard hemodialysis}

SI «Institute of Nephrology of the National Academy of Medical

Sciences», Kyiv, Ukraine

\section{Citation:}

\section{Article history:}

Received May 20, 2019 Received in revised form October 07, 2019 Accepted October 10, 2019
Aleksieieva N. Advantages of expanded hemodialysis (HDx) over standard hemodialysis. Ukr J Nephr Dial. 2019;4(64):56-61. doi: 10.31450/ ukrjnd.4(64).2019.08
Abstract. Chronic kidney disease leads to the accumulation of a wide range of uremic toxins. Negative effects of uremic toxins are most likely due to the combined effects of many uremic solutes, including small molecules, middle molecules, and soluble protein-linked substances. Large and medium-sized molecules are directly associated with chronic inflammation and adverse effects, including major cardiovascular risks and consequently poor prognosis.

Recent advances in chemical composition and new production techniques led to improved biocompatibility and selective permeability of dialysis membranes. Specifically, the creation of a new class of membranes provided the possibility to improve the clearance of medium to high molecular weight (MW) solutes (i.e. uremic toxins in the range of $5-50 \mathrm{kDa}$ ).

The new HDx therapy (expanded HD) is the next evolution in hemodialysis, as it effectively targets the removal of large middle molecules. The HDx therapy is enabled by the THERANOVA dialyzer featuring an innovative membrane that combines a higher permeability than regular high-flux dialyzers with effective selectivity for large proteins.

Expanded hemodialysis is an advanced therapy targeting large and medium-sized molecules that are currently not possible to remove by modern dialysis methods including traditional hemodialysis (HD) and hemodiafiltration (HDF). HDx became possible due to THERANOVA, a new dialyzer with an innovative membrane. The THERANOVA-based HDx provides a great new opportunity for dialysis patients, providing unique high-efficiency hemodialysis with the usage of already available infrastructure and standard HD workflows.

Keywords: dialysis membranes, expanded hemodialysis, THERANOVA, HDx, uraemic toxins, haemodiafiltration.

Conflict of interest statement: this work was supported by an academic support grant provided by the Baxter.

(C) N.G. Aleksieieva, 2019. All rights reserved. Correspondence should be addressed to Nataliia Aleksieieva: redialis@ukr.net 
(с) Алексєєва Н. Г., 2019

УДК 616.61-085.38-073.27

\title{
Н.Г. Алексєєва
}

\section{Переваги розширеного гемодіалізу (HDx) перед стандартним гемодіалізом}

\author{
ДУ «Нститут нефрології НАМН України», м.Київ
}

Резюме. Хронічна хвороба нирок (ХХН) призводить до накопичення широкого спектру уремічних токсинів, негативні ефекти яких, ймовірно, обумовлені комбінованим впливом їх розмаїття, що включає малі молекули, середні молекули й розчинені речовини, зв'язані з білками. Накопичення саме великих середніх молекул в організмі хворого на діалізі призводить до хронічного запалення і відповідно підвищених серцево-судинних ризиків та, як наслідок, несприятливого прогнозу.

Останні досягнення у технології виробництва діалізних мембран призвели до поліпшення їх біосумісності й селективності щодо великих середніх молекул за рахунок розробки нової хімічної складової мембрани та особливої тришарової структури із збільшеним діаметром пор. Інноваційна щодо видалення крупних середніх молекул високопроникна діалізна мембрана діалізатору THERANOVA, дозволила впровадити якісно новий вид діалізної терапії у світову нефрологічну практику - розширений гемодіаліз (HDx) / (рГД).

Таким чином, HDx став черговою еволюцією діалізної терапії, оскільки ефективно спрямований на видалення тих середніх молекул, які не видалялися раніше сучасними методами діалізу, включаючи як традиційний гемодіаліз (ГД), так і гемодіафільтрацію (ГДФ).

Ключові слова: діалізні мембрани, розширений гемодіаліз, HDx, рГД, THERANOVA, великі середні молекули, гемодіафільтрація.

Лікування хронічної хвороби нирок V стадії (XXН V ст.) є серйозною проблемою в усьому світі. На даний час хворі на ХНН V ст., що лікуються гемодіалізом, переважно отримують низькопоточний гемодіаліз (LF-HD), високопоточний (HF-HD) або гемодіафільтрацію (HDF). Однак, очищення від середніх та великих молекул, що входять до складу відомого переліку уремічних токсинів, залишається недостатнім при LF-HD, HFHD, HDF i on-line HDF [1]. Таким чином, виникла гостра необхідність поліпшення гемодіалізних технологій й структурної складової виробництва витратних матеріалів для ГД, а саме: розробка таких мембран, що видаляли би високомолекулярні сполуки, збільшували кліренс уремічних токсинів та в практичному застосуванні не викликали значної втрати альбуміну.

Першим етапом цього процесу було створення апаратури з системами ультрафільтрації (УФ), що забезпечили можливість широкого застосування НF-мембран. Завдяки високій гідравлічній проникності й більшому розміру пор, HF- мембрани краще виводять середні молекули при високопоточному гемодіалізі [2, 3]. Подальший науково-технологічний пошук та еволюція діалізних технологій призвели до створення мембран для високооб’ємної ГДФ [4], які є більш ефективними, ніж звичайні HF-мембрани, але й разом з тим призводять до збільшених втрат альбуміну. За цих обставин, розчинені речовини з високою МВ, такі як цитокіни, міоглобін або вільні легкі ланцюги (FLC) $є$ основними мішенями для їх видалення.

Необхідно окреслити основні три категорії небілково-зв'язаних уремічних розчинених речовин, які накопичуються при ХХН (Таблиця 1):

1. Малі молекули < 500 Да (ефективне видалення шляхом дифузії)

2. Звичайні середні молекули $500-15000$ Да (обмеженість видалення шляхом дифузії компенсується застосуванням конвекції)

3. Великі середні молекули 15000 - 60000 Да (для ефективного видалення потрібні мембрани 3 більш високою проникністю)

Алексєєва Наталія Григорівна redialis@ukr.net 
Таблиия 1

\section{Спектр уремічних токсинів в залежності від молекулярної маси} та відповідних клінічних ефектів

\begin{tabular}{|c|c|c|c|}
\hline $\begin{array}{l}60 \text { Да } \\
125 \text { Да } \\
461 \text { Да }\end{array}$ & $\begin{array}{l}\text { Сечовина } \\
\text { Креатинін } \\
\text {-ліпотропін }\end{array}$ & Загальна уремічна токсичність & $\begin{array}{l}\text { Малі молекули } \\
\text { < } 500 \text { Да }\end{array}$ \\
\hline 1200 Да & -2-мікроглобулін & $\begin{array}{c}\text { Амілоїдоз } \\
\text { Карпальний тунельний синдром }\end{array}$ & $\begin{array}{c}\text { Звичайні середні } \\
\text { молекули } \\
500-15000 \text { Да } \\
\end{array}$ \\
\hline 16000 Да & Лептин & Зниження апетиту & \multirow{8}{*}{$\begin{array}{c}\text { Великі середні молекули } \\
>15000 \text { Да }\end{array}$} \\
\hline 18000 Да & Мікроглобулін & $\begin{array}{c}\text { Оксидативний стрес } \\
\text { Мітохондріальна дисфункція }\end{array}$ & \\
\hline 23000 Да & $\begin{array}{l}\text { Капа вільні легкі } \\
\text { ланцюги } \\
\end{array}$ & Множинна токсичність & \\
\hline 25000 Да & Інтерлейкін-6 & Запалення & \\
\hline 27000 Да & Гепсидин & Анемія & \\
\hline 43000 Да & Пентраксін-3 & ЦРБ & \\
\hline 45000 Да & $\begin{array}{l}\text { Лямбда вільні } \\
\text { легкі ланцюги }\end{array}$ & Кардіо-васкулярний компонент запалення & \\
\hline 51000 Да & TNF- & Сепсис, запалення & \\
\hline 68000 Да & Альбумін & Зв’язування токсину & Життєво важливі білки \\
\hline
\end{tabular}

Науковці намагалися знайти зв'язок між наявністю уремічних токсинів з розмірами молекул в діапазоні 5000 - 50000 Да, які адекватно не видаляються методиками поточного гемодіалізу, та такими ускладненнями, як анемія, ураження скелетної системи, полінейропатія та діаліз-асоційований амілоїдоз у пацієнтів з адекватними показниками сечовини та Kt/V [5-7]. Було виявлено класичні та нові молекулярні сполуки, що вносили вагомий вклад у рівень загальної уремії $[5,6,8]$. Зокрема, високі рівні паратиреоїдного гормону, фактору росту фібробластів-23, остеокластину, остеопротегерину та інші задіяні молекули у кістковому та кальційфосфорному метаболізмі, асоціювалися з остеодистрофією. Гепсидин і білки, що інгібують кістковий мозок і еритропоез викликали уремічну анемію. Гомоцистеїн і медіатори запалення корелювали з прискореним прогресуванням атеросклерозу й серцево-судинними ускладненнями. Підвищений рівень лептину призводив до значного зниження апетиту. Нещодавно лямбда вільні легкі ланцюги ( $\lambda$-FLCs - 22000 Да) і капа вільні легкі ланцюги (к-FLCs 42000 Да) також були ідентифіковані як токсичні молекули у уремічних хворих [5].

Класичні НF-мембрани ефективно видаляють невеликі та деякі середні молекули, але не ефективні щодо великих середніх молекул. При використанні мембран для високооб'ємної ГДФ, найважливішою детермінантою є видалення бета-2 мікроглобуліну $(\beta-2 \mathrm{M})[6,7,9,10]$. Проведені дослідження окреслили можливості застосування ГДФ, як техніки, що дає змогу максимально використовувати пропускну здатність таких мембран [1, 6, 9].
Проте великі середні молекули, напряму асоційовані із хронічним запаленням та кардіоваскулярними подіями (рис. 1), довгий час залишалися недосягнутими мішенями щодо їх ефективного видалення.

3 метою ефективного видалення зазначених уремічних токсинів і підвищення селективної проникності мембрани, нещодавно була розроблена тришарова мембрана із збільшеним розміром пор, що визначена як мембрана 3 середньою точкою відсікання (middle cut-off, MCO) [8, 11], яка забезпечує видалення молекул більшого розміру [12]. Діалізна терапія з використанням такої технології отримала назву розширений гемодіаліз (HDx) / (рГД) [13].

Розширений гемодіаліз - це вдосконалена діалізна терапія, націлена на видалення великих середніх молекул, які на сьогодні не виводяться сучасними методами діалізу, включаючи традиційний ГД і ГДФ. НDх став можливим завдяки THERANOVA - новому діалізатору з інноваційною мембраною [13]. HDx на основі THERANOVA уявляє собою варіант діалізної терапії для пацієнтів, які потребують високої якості лікування та, разом з тим, має ефективні показники економіки бюджетного ресурсу, що витрачається на високоякісну діалізну терапію, за рахунок відсутності необхідності у додатковій підготовці значного обсягу води для проведення ГДФ.

В Таблиці 2 представлено діалізні мембрани за радіусом пор [12]. 


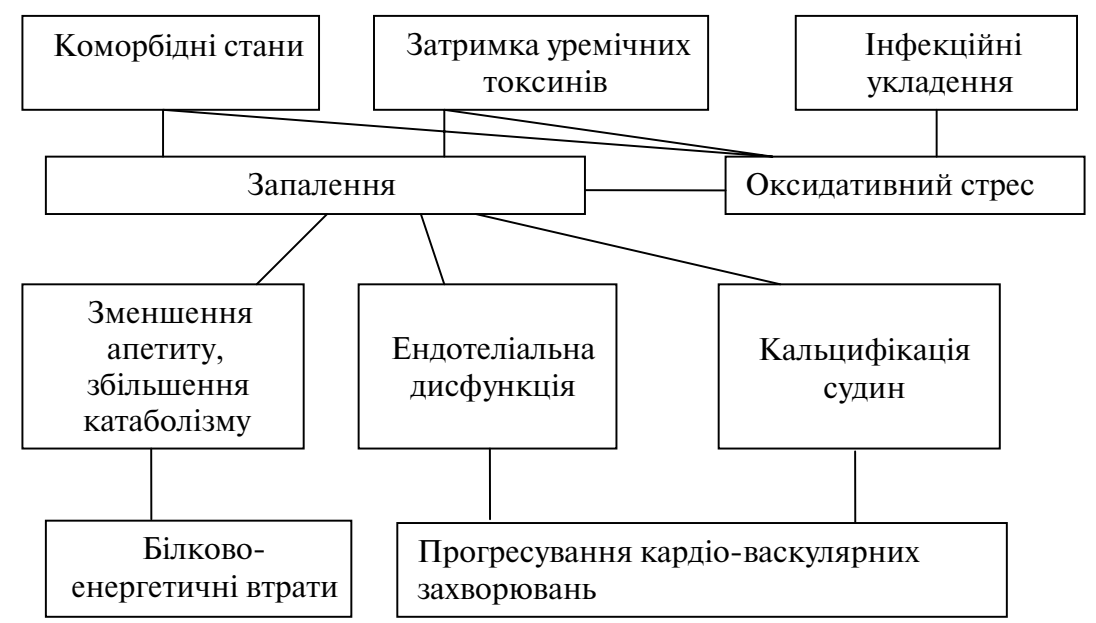

Рис. 1. Взаємозв’язок середніх молекул з ризиком запалення та кардіоваскулярними подіями.

\section{Таблиия 2}

\section{Радіуси пор та логарифмічне значення утримання (LRV) при різних типах мембран}

\begin{tabular}{|c|c|c|}
\hline Тип мембрани & Радіус пор [нм] & LRV \\
\hline Низькопоточна & - & $2,8 \pm 0,2$ \\
\hline Високопоточна & $2,68 \pm 0,02$ & $3,3 \pm 0,2$ \\
\hline $\begin{array}{c}\text { Мембрана для розширеного } \\
\text { гемодіалізу (НDx) }\end{array}$ & $3,5 \pm 0,3$ & $3,5 \pm 0,2$ \\
\hline
\end{tabular}

Структура мембрани THERANOVA є асиметричною і має три окремих шари (рис. 2).

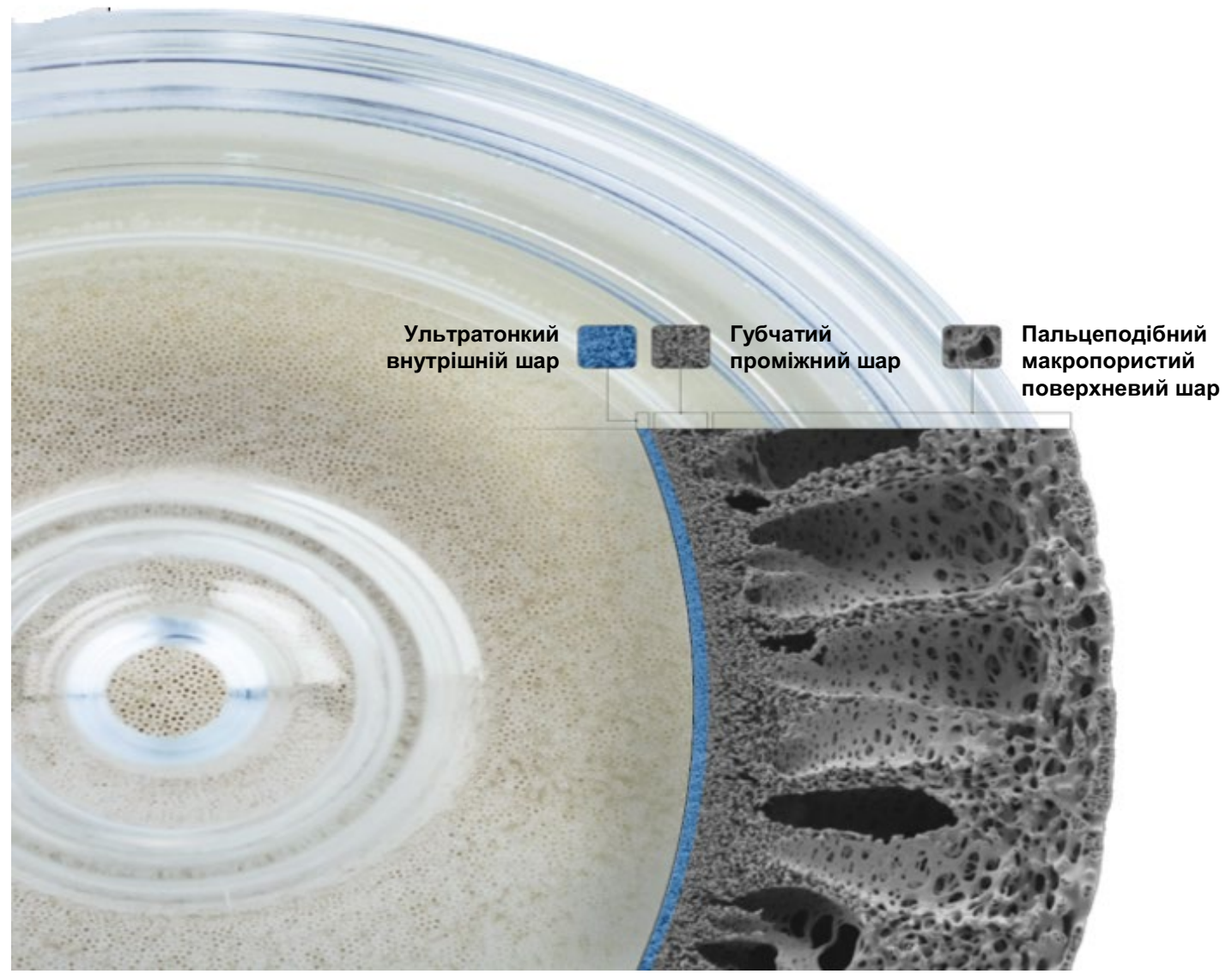

Рис. 2. Пошарова будова мембрани THERANOVA. 
Гладка поверхня поверхневого шару, що контактує з кров’ю, містить гідрофобні / гідрофільні мікродомени, що дозволяє мінімізувати взаємодію з компонентами крові, зменшує адсорбцію білка і клітинну взаємодію, забезпечуючи менші ризики тромбоутворення.

Адсорбційні властивості мембрани THERANOVA забезпечують той же рівень затримки ендотоксинів, як і інші стандартні діалізні мембрани. Незважаючи на свою більш високу проникність, мембрана THERANOVA представляє собою безпечний і ефективний бар'єр для екзотоксинів. Вона сумісна із стандартними розчинами і не вимагає додаткового контролю якості води.
Внутрішній діаметр мембрани THERANOVA значно зменшений з метою підвищення внутрішньої фільтрації вздовж мембрани, що сприяє високій ефективності видалення великих середніх молекул [13].

Таким чином, інноваційна конструкція мембрани і діалізатору поєднує в собі як високу проникність для середніх молекул та ефективну селективність, так і посилену внутрішню фільтрацію.

Завдяки своїй унікальній тришаровій конструкції з переплетеними асиметричними волокнами в мембрані та збільшеному діаметру пор, діалізатор THERANOVA наближується ще на крок до структури нативної нирки (рис. 3).

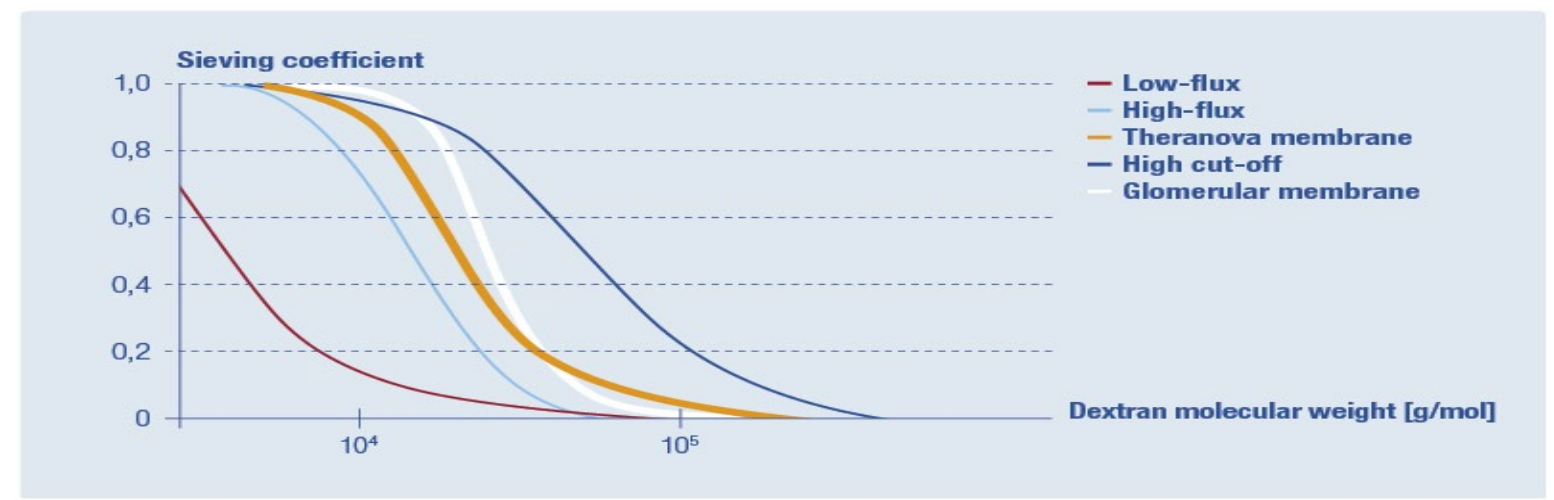

\begin{abstract}
A STEP CLOSER TO THE NATURAL KIDNEY
By expanding the range of solutes removed in dialysis, while retaining selectivity towards albumin and other essential proteins, the THERANOVA dialyzer is coming a step closer to the natural kidney.14,15
\end{abstract}

Рис. 3. Видалення середніх молекул при різних типах мембран.

За результатами даних, що отримані за умов використання різних високопоточних діалізаторів при різних режимах розведення (пост- та пре-дилюція з різними конвективними обсягами), застосування HDx забезпечує мінімальне видалення альбуміну у порівнянні з ГДФ-межами виведення альбуміну під час однієї сесії (рис. 4).

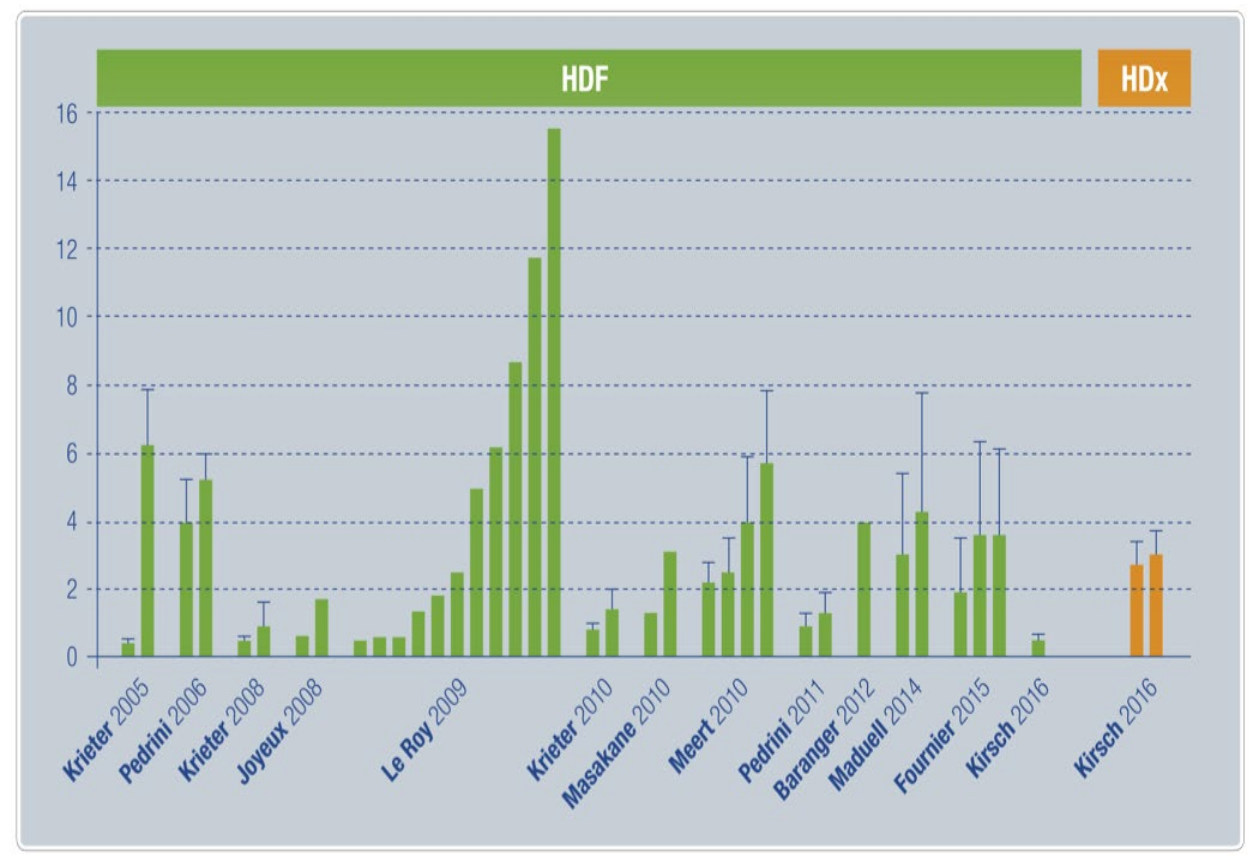

Рис 4. Дані по виведенню альбуміну при ГДФ (комерційно доступні діалізатори) і HDx (Theranova). 


\section{Висновки:}

1. За рахунок створення інноваційної мембрани діалізатору THERANOVA, впроваджено новий метод діалізної терапії - розширений гемодіаліз (HDx), що забезпечує краще інтрадіалізне видалення великих середніх молекул, ніж при звичайному ГД та ГДФ при однакових швидкостях кровотоку.

2. HDx дозволяє економити бюджетні кошти через уникнення додаткових експлуатаційних витрат, пов'язаних з широкозастосованою в Україні процедурою ГДФ, призначення якої найчастіше немає достатнього клінічного обгрунтування. При застосуванні HDx відсутня необхідність у спеціальних ультрафільтрах для ГДФ, підготовці додаткових обсягів води і концентратів, а сама технологія процедури відповідає звичайному ГД.

Конфлікт інтересів: робота підтримана науковим грантом, наданим компанією Baxter.

\section{Лiтература (References):}

1. Chapdelaine I, et al. Optimization of the convection volume in online post-dilution hemodiafiltration: practical and technical issues. Clin Kidney $\mathbf{J}$ (2015);8:191-8. doi: 10.1093/ckj/sfv003.

2. Ronco $C$. Hemodiafiltration: evolution of a technique towards better dialysis care. Contrib Nephrol 2011; 168: 19-27. doi: 10.1159/000321741.

3. Ronco C, Crepaldi C, Brendolan A et al. Evolution of synthetic membranes for blood purification: the case of the Polyflux family. Nephrol Dial Transplant 2003; 18(Suppl 7): vii10-vii20 doi: 10.1093/ndt/ gfg 1073 .

4. Ward RA. Protein-leaking membranes for hemodialysis: a new class of membranes in search of an application? J Am Soc Nephrol 2005; 16:2421-2430. doi: 10.1681/ASN.2005010070.

5. Jankowska M., Cobo G., Lindholm B. et al. Inflammation and protein-energy wasting in the uremic milieu. Contrib. Nephrol. 2017;191:58-71. doi: 10.1159/000479256.

6. Navarro V, Carmen MC, Torregrosa E, Simon V, et al. Am. J. Kidney Dis. 2002;40:582-9. doi: 10.1053/ ajkd.2002.34918.

7. Zickler D., Schindler R., Willy K. et al. Medium cut-off (MCO) membranes reduce inflammation in chronic dialysis patients- a randomized controlled clinical trial // PLoS One. 2017;12. doi: 10.1371/ journal.pone.0169024.
8. $Y u X$. The evolving patterns of uremia: unmet clinical needs in dialysis. Contrib Nephrol 2017;191:1-7 doi: 10.1159/000479251.

9. Hutchison C.A., Wolley M. The rationale for expanded hemodialysis therapy (HDx). Contrib. Nephrol. 2017;191:142-152. doi: 10.1159/000479262.

10. Bourguignon $C$, Chenine L, Bargnoux AS, LerayMoragues H, Canaud B, Cristol JP, Morena M. Hemodiafiltration improves free light chain removal and normalizes $\kappa / \lambda$ ratio in hemodialysis patients. J Nephrol. 2016 Apr;29(2):251-257. doi: 10.1007/s40620-015-0207-z.

11. Ronco C., Marchionna N., Brendolan A., Neri M., LorenzinA., Martinez Rueda A. Expanded haemodialysis: from operational mechanism to clinical results. Nephrol. Dial. Transplant. 2018;33(3):iii41iii47. doi: 10.1093/ndt/gfy202.

12. Hulko $M$, et al. Dialysis membrane pore size does not determine LPS retention. ERA-EDTA 2015, Abstract FP516.

13. Baxter. Data on file. THERANOVA Limited Controlled Distribution Report 2016 [Internet]. Available from: https://renalcare.baxter.com/ sites/g/files/ebysai1471/files/2019-01/EUMPMG209-16-0038_Theranova_LCD_FINAL.pdf. 